\title{
THE EFFECT OF FINANCIAL AND NON-FINANCIAL VARIABLES ON UNDERPRICING
}

\author{
Dyan Fajar Mahardikai, \\ Fitri Ismiyanti \\ Master of Management Study Program, \\ Faculty of Economics and Business, \\ Airlangga University Surabaya, \\ Indonesia
}

\begin{abstract}
:
After the shares were introduced to the public by the underpricing company (IPO), the problem lies in the closing price on the first day which tends to be higher than the initial offering price. Various factors can influence the occurrence of underpricing, both external and internal, that occurs in Islamic stocks. This study examines more about the influence of financial and non-financial variables on underpricing shares, especially in Islamic stocks. The population used includes, among others, listed companies on the IDX with a sample of issuers that went public from 2015 to 2019. Data analysis in this study used multiple regression. The results of the study prove that block holders in a company have an effect on the level of underpricing. Debt to Equity Ratio (DER) have an effect on the underpricing variable. Return on Asset (ROA) harms the underpricing variable. There is an effect of the current ratio value on underpricing. Firm size has an effect on underpricing. Company age (firm age) has an effect on the underpricing variable.
\end{abstract}

JEL: D53; E44; G10

Keywords: underpricing, initial public offering, financial factors, non-financial factors

\section{Introduction}

Companies' access to obtain funding is now becoming more and more a choice. For companies, funding is an important point to maintain the sustainability of their business. The company has alternative sources of funding that can be obtained from within the company and outside the company. Several alternatives for companies to get funding include increasing their own capital, issuing bonds, debt to banks, and launching new shares (Putra and Nababan, 2019). Meanwhile, companies that have not been listed on

i Correspondence: email. dyan.idx@gmail.com 
the Indonesia Stock Exchange and have the desire to go public, must conduct an Initial Public Offering (IPO) on the primary market.

Before the company's shares can be traded on the IDX, the company must go through a process of going public. First, shares are traded on the primary market, then shares are traded on the secondary market. The price of shares sold in the primary market has been determined in advance based on an agreement between the issuer and the underwriter. The underwriter in this case has better information about the demand for shares owned by the issuer than the issuer itself. When a company conducts an IPO, the price of shares sold in the primary market is determined by an agreement between the issuing company and the underwriter, while the price that occurs in the secondary market after the company's IPO is determined by the existing market mechanism through the power of demand and supply of shares. in the capital market (Herawati, 2017).

The underpricing problem that arises related to the IPO is that after the shares are introduced to the public by the underwriting company, the closing price on the first day is usually higher than the initial offering price (Florin and Simsek, 2007). Underpricing refers to the closing price of the shares on the first trading day which is higher than the issue price originally paid by the customer. Underpricing is also often referred to as early return. If investors get an allocation in an IPO, and turn over these shares on the day the company is listed, then their average return will be higher than the market price (Asiri \& Haji, 2015). Most IPOs trade at a higher price on the day of listing, meaning that companies can earn more money if they have set a higher bid price than they actually charge. These differences indicate that investors have different beliefs about the company's future, such as the belief that the company has been assessed incorrectly and deserves a higher price. This results in an increase in demand and prices for goods in the secondary market. The higher the amount of underpricing, the more money the company can make through the higher bid price.

The IPO underpricing phenomenon can be explained comprehensively by the signaling theory. Signaling theory assumes that the issuer has perfect information about the firm's value, while investors do not know the company's detailed information, which then values the company through different methods. During an IPO, the underwriters will usually reduce the initial share price, this is done to reduce the risk of overpricing. Therefore, this theory predicts that if the emission value decreases, the level of underpricing will increase. This is because in most cases, the value of the publication is directly related to the value and size of the issuing company.

A number of studies have studied empirical evidence regarding underpricing signals in companies conducting IPOs. The importance of the initial stock price has prompted several researchers to further analyze the factors that influence underpricing which then causes the initial return. Previous studies have been carried out to test whether there is a tendency for underpricing in companies conducting IPOs. Kusminto (2017) explains that the variable offering size, underwriter reputation and DER has a positive effect on underpricing, while the variables of company age, government ownership, ROA and percentage of shares have a negative effect on underpricing. Saputra and Sitinjak (2018) concluded that the variables Current Ratio, ROA, RPD, 
auditor reputation, herding phenomenon, and exchange rates negatively affect the underpricing of companies that make initial public offerings on the Indonesia Stock Exchange. Meanwhile, the leverage ratio (DER) has a positive effect on underpricing in companies that make initial public offerings on the Indonesia Stock Exchange. Thoriq et al (2018) concluded that ROA, DER, AGE, and inflation have an effect on underpricing, while Size, Industry Type, Underwriter Reputation and Exchange Rate have no effect on underpricing. Mayasari, Yusuf and Yulianto (2018) concluded that ROE and Firm Size have an effect on underpricing, while Net Profit Margin has no effect on underpricing. From the differences in the results of these studies, it is interesting to conduct a review of the factors that affect the underpricing of Islamic stocks that are IPO on the IDX for the period 2008-2018. Increasingly aggressive financial literacy and inclusion have made sharia stocks attractive to investors. It is proven that based on the IDX data report (2016) since the launch of Islamic stocks, it has actually grown higher or by $17.11 \%$ compared to the JCI in the same period of $12.74 \%$. This is in line with IDX data regarding the increasing number of Islamic investors (Figure 1).

Figure 1: Number of Sharia Investors

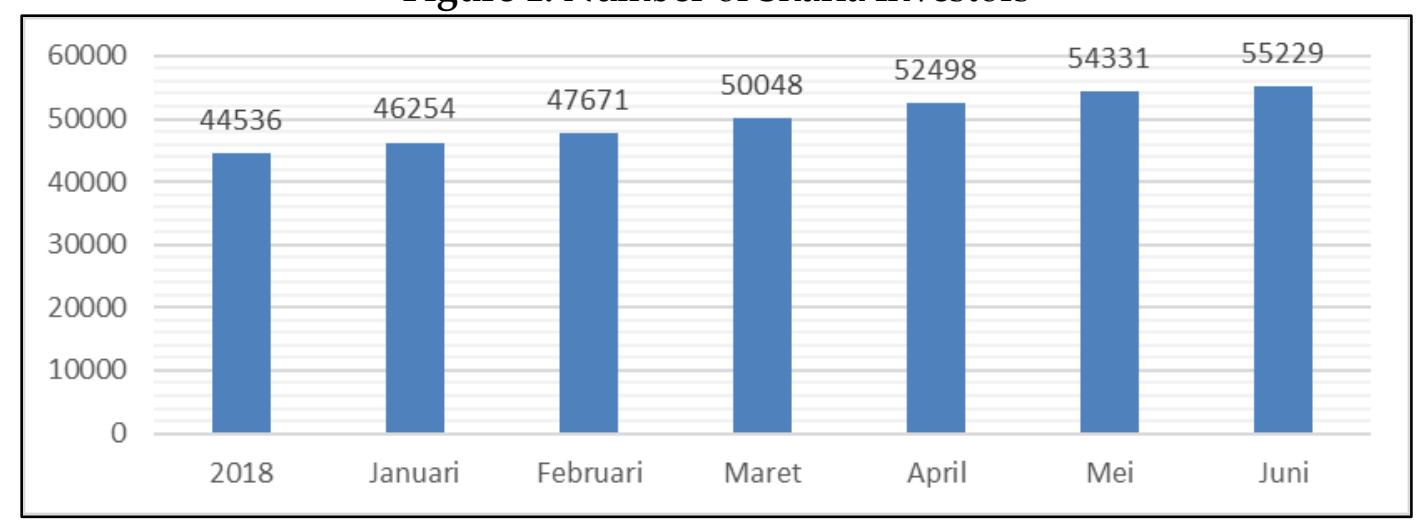

Source: IDX Islamic, 2018.

Based on the background that has been described, the researcher examines more deeply the influence of financial and non-financial variables on underpricing shares, especially in Islamic stocks. The results given for the country analysis include only an overview of how the mean, standard deviation, and minimum and maximum yields are realized in the IPO. In addition, the variables used in the measurement tend to be financial aspects. So that often it is still unable to achieve convergence related to underpricing on Islamic stocks. Therefore, studying the non-financial aspects is necessary in understanding the more comprehensive characteristics related to underpricing on Islamic stocks. This will help a variety of not only investors but stakeholders (stakeholders) to change the pattern of underpricing. 


\section{Literature Review}

\subsection{Signaling Theory}

According to Brigham and Hauston (2009), a signal is an action taken by a company to provide guidance to investors about how management views the company's prospects. This signal is in the form of information about what management has done to realize the owner's wishes. The information released by the company is important, because it affects the investment decisions of parties outside the company. This information is important for investors and business people because information essentially provides information, notes or descriptions, both for the past, present and future conditions for the survival of the company and how it affects the company.

Signaling theory explains why companies have the urge to provide financial statement information to external parties. The encouragement of companies to provide information to stakeholders will lead to asymmetric information between the company and outside parties. This is because the company knows more information about the company and its future prospects than outsiders. Lack of information for outsiders about the company causes them to protect themselves by charging the company low prices. Companies can increase firm value by reducing asymmetric information. One way to reduce asymmetric information is to provide signals to outsiders.

Broadly speaking, the signaling theory is closely related to the availability of information. Financial reports can be used to make decisions for investors, financial reports are the most important part of a company's fundamental analysis. The rating of companies that have conducted IPOs is usually based on financial ratio analysis. The analysis is carried out to facilitate interpretation of the financial statements that have been presented by the company.

In the use of signaling theory, company financial information such as Return On Assets (ROA) provides information that high ROA will indicate the company's performance is good. This information will be a good signal for investors. High profitability shows that the company's prospects are good, so investors will respond positively to these signals and the company's value will increase.

\subsection{Underpricing}

Underpricing is a condition where the share price at the time of the initial offering is lower than when it was traded on the secondary market. Underpricing is a term used when the stock price of a company that has just gone public is below the stock price when it was traded on the first day of listing (Dimovski \& Brooks, 2008). Some literatures explain that underpricing occurs because of the presence of asymmetric information. The parties that determine the share price at the IPO are the issuer and the underwriter. In Baron's model (Dimovski, et al., 2008), asymmetric information can occur between issuers and underwriters. This model assumes that the underwriter has more information about the demand for shares of the issuing company than the issuing company itself. Therefore, underwriters will use the information they have to make an optimal IPO price agreement 
for themselves, namely by reducing the risk in the form of having to buy unsold shares. Issuers will receive a cheap price for their share offering because they lack information.

This model implies that the greater the issuer's uncertainty about the fairness of its share price, the greater the demand for underwriting services in setting prices. Compensation for the information provided by the underwriter is to allow the underwriter to offer the initial price of its shares below the equilibrium price. Thus, the greater the uncertainty, the greater the risk faced by the underwriter, which will lead to a higher underpricing level.

In the Rock model (Dimovski, et al., 2008) it is assumed that asymmetric information occurs in groups of investors who have information about the prospects of the listed company. A group of investors who have better information will buy the shares of the IPO if it will provide a return, while the group of investors who are less informed about the prospect of the issuing company will buy shares arbitrarily, both underpriced and overpriced stocks. As a result, the uninformed group will get a greater proportion of overpriced stocks. The groups that do not have this information will leave the primary market because they have more to lose. So that all groups participate in the primary market and it is possible to get that return reasonable and can cover losses due to the purchase of overpriced shares, then the IPO must be sufficiently underpriced.

\subsection{Debt to Equity Ratio (DER)}

Debt to equity ratio (DER) is one of the leverage ratios. DER reflects the company's ability to meet all of its obligations, which is shown by some of the shares of its own capital used to pay debts. DER shows the level of leverage (use of debt) compared to the company's own capital. DER also provides assurance about how much the company's debt is guaranteed by the company's own capital which is used as a source of business funding (Ang, 1997). The greater the DER value, it means that the business capital structure uses more debt relative to equity. The greater the DER reflects a relatively high company risk; as a result, investors tend to avoid stocks that have a high DER value (Ang, 1997). A high DER value will increase investor uncertainty and will increase the level of underpricing (Kim, et al., 1995). So that the probability of return that investors will receive is even greater. Thus, it is assumed that the greater the DER value of a company, the greater the initial return and return 7 days after the IPO.

\subsection{Return On Asset (ROA)}

Return On Assets (ROA) is the ratio between Earning Before Interests and Taxes (EBIT) and the book value of all assets at the time of the IPO, as a measure of profitability ( $\mathrm{Su}$, 2004). Su (2004) argues that ROA has a negative effect on underpricing, while Ardiansyah's (2004) research shows that ROA has no effect on underpricing. Based on the results of research by Su (2004), when market conditions at the time of the IPO were good, the level of underpricing of the IPO was relatively low. ROA is a measure of a company's profitability, so the higher the company's ROA, the lower the level of underpricing (the difference between the stock price on the first day of listing and the 
initial stock price is getting lower) because investors will judge the company's performance better and are willing to buy its first shares at a higher price. high.

\subsection{Quick Ratio (Acid Test Ratio)}

The definition of Acid Test Ratio, according to Munawir (2001), is the ratio of current assets minus inventories to current debt. This ratio is a measure of a company's ability to meet its obligations without taking into account inventory, because inventory takes a relatively long time to be turned into cash, and assumes that receivables can immediately be converted into cash, even though in reality the inventory is more liquid than the accounts receivable.

This ratio is sharper than the Current Ratio, because it only compares highly liquid assets (easily cashed out) with current debt. If the Current Ratio is high but the Quick Ratio is low it indicates a very large investment in inventory.

\subsection{Firm Size}

Firm size can be used as a proxy for the level of uncertainty of shares because large-scale companies tend to be better known to the public, so that information about the prospects of large-scale companies is easier for investors to obtain than small-scale companies. The level of uncertainty that potential investors will face regarding the future of the listed company can be minimized if the information they get is a lot (Ardiansyah, 2004).

The level of uncertainty of large-scale companies is generally low because with a high scale companies tend not to be influenced by the market, on the contrary it can color and influence the overall market condition. This situation can be expressed as the small level of investment risk of large-scale companies in the long run. Whereas in small-scale companies the level of uncertainty in the future is large, so that the level of investment risk is greater in the long term (Nurhidayati, et al., 1998).

With the low level of uncertainty for large-scale companies, it will reduce the level of underpricing and the lower the probability of return that investors will receive (Kim, et.al. 1995). Therefore, it is assumed that the larger the company size, the smaller the initial return and return 7 days after the IPO. According to Kim et.al. (1995) and Carter, et al. (1998), firm size has a significant effect on underpricing. Likewise, the results of Wahyudi's (2004) research show that firm size has a significant positive effect on underwriters and initial stock returns. Meanwhile, Ardiansyah's research (2004) states that company size does not have a significant effect on initial returns and returns 15 days after IPO. Similar to the research results of Nurhidayati \& Indriantoro (1998) that company size has no effect on the level of underpriced.

\subsection{Blockholder Ownership}

Blockholder ownership is the largest number of shareholdings in a company which is more than $20 \%$, ownership of more than $20 \%$ is considered to increase the control effectiveness of shareholders (Porta, et al. 1999). Blockholder ownership can come from agencies and individuals who have the ability to professionalism in running and 
controlling the company, the higher blockholder ownership in the company, if it can carry out its function properly, it will increase the company's value (Thomsen, et al. 2004) The higher the ownership in the company, the lower the willingness and opportunity for management to misuse resources, while the high distribution of ownership causes management to be unable to be properly monitored because shareholders lose control. Increasing company ownership is also one way of reducing agency conflicts and agency costs (Berle, et al., 1932). The higher the proportion of share ownership in a company will have a greater role and opportunity in maximizing firm value (Jasen, et al., 1976).

The existence of blockholder ownership has an important meaning in monitoring management. Ownership by institutions such as insurance companies, banks, investment companies and ownership by other institutions will encourage increased supervision more optimally. This monitoring mechanism will ensure an increase in the prosperity of shareholders. The significance of stockholder ownership as a supervisory agent is emphasized through their substantial investment in the capital market. If blockholder ownership is dissatisfied or managerial performance, they will sell their shares to the market (Ardiningsih, et al., 2010)

Blockholder ownership can also increase agency conflicts between blockholders and minority investors. This is because blockholders have the urge to use their voting power, so that they can enjoy the income or profits of the company that are distributed to minority shareholders (Becht, et al., 2002).

\subsection{Underwriter's Reputation}

An underwriter or underwriter is a party that makes an issuer's contract to make a public offering for the interest of the Issuer with or without the obligation to buy the remaining unsold securities. According to Gumanti (2002), there are several reasons that underwriters are still used, namely: There is an assumption that underwriters are able to increase stock prices, there is a guarantee of the success of selling shares. The Issuer will be able to receive the offer results immediately after the transaction or agreement with the underwriter and underwriter services is very helpful for the issuer in conducting an IPO.

\subsection{Age Firm}

Company age is one of the things that investors consider when investing (Chistyet, et al. 1996). The age of the company shows how long the company has been able to survive and is proof that the company is able to compete and can take advantage of existing business opportunities in the economy. In this case, there are factors that indicate that the relationship between firm size and performance of large IPO firms will attract underwriters (Carter, et al., 2009).

Companies that have operated for longer periods of time have a greater ability to provide more and broader company information than those that have just been established (Nurhidayati, et al., 1998). Wahyudi (2004) explains that the age of the company is calculated by subtracting the year of offering at the IPO with the year when the company was founded. Companies that are older and mature can be perceived as 
companies that have withstood the test so that the level of risk is low and this can attract investors because it is believed that companies that have long been established can be said to be more experienced in generating returns for companies which in turn have an impact on increasing returns received by investors. Therefore, it is assumed that the more age the company is, the greater the initial return and return 7 days after the IPO.

\section{Method}

This study takes a population of companies listed on the IDX by taking a sample of companies that go public in 2015 to 2019. The population in this study amounted to 98 issuers. The sampling technique was purposive sampling. The companies used as samples are non-financial companies, because financial companies are heavily influenced by government regulations, thus affecting capital structure decisions.

The operational definition of a variable is a definition that provides the meaning needed to measure a variable. As for the operational definition in this research is Underpricing is a condition where the price of shares offered on the primary market is lower than the stock price after being traded on the secondary market. This variable is measured using the following formula:

Underpricing $=\frac{\text { Closing Price }(\text { Pasar sekunder })-\text { opening Price }(\text { IPO) }}{\text { Opening Price }(\text { IPO })} \times 100 \%$

Blockholder Ownership is a company ownership structure. Blockholders are shareholders whose ownership is at least $5 \%$ of the total shares of the company (Thomsen, Pedersen and Kvist, 2006). Blockholder Ownership describes the ratio of shares owned by blockholders and can be calculated using the following formula (Wiliandri, 2011):

Blockholder Ownership $=\frac{\text { Shares owned by blockholders }}{\text { Number of shares outstanding }}$

The underwriter's reputation in this study uses measurement data based on the underwriter's most active ranking. This study determines a value of 0 for underwriters who are not included in the top ten group and a value of 1 for underwriters who are not included in the top ten group. This research was conducted over a period of 5 years, namely 2015-2019 during the study.

Debt to Equity Ratio (DER) is a comparison between total debt (current debt and long-term debt) and capital which shows a company's ability to meet its obligations using existing capital (Riyanto, 2008). This ratio is the leverage ratio. The DER measurement scale is based on the following formula (Suad, 2004).

Debt to equity ratio $($ DER $)=\frac{\text { Total Payable }}{\text { Equity }} \times 100 \%$ 
ROA is a profitability ratio that measures a company's ability to generate profits from the assets used. Return on Assets is a comparison between net income after tax and total assets owned by the company. Positive Return on Assets (ROA) shows that of the total assets used to operate, the company is able to provide profits for the company. The ROA value can be measured by the formula:

Return on Assets $($ ROA $)=\frac{\text { net profit after tax }}{\text { Total Asset }} \times 100 \%$

Quick ratio or Current ratio (CR) is a comparison between current assets and current liabilities and is the most commonly used measure to determine a company's ability to meet its short-term obligations. This ratio is one of the liquidity ratios. The current ratio measurement scale with the following formula (Munawir, 2004):

Current Ratio $($ CR $)=\frac{\text { Current Assets }}{\text { Current Liability }} \times 100 \%$

Firm Size can be used as a proxy for the level of uncertainty of shares. Large-scale companies tend to be better known by the public, so that information about the prospects for large-scale companies is easier for investors to obtain than for small-scale companies. Company size is calculated using the logarithm of the company's total assets.

Size $=$ Ln (Total Asset)

The age of the company (Age Firm) shows how long the company is able to survive. The longer the life of the company, the more information the public has about the company.55 This will reduce information asymmetry and reduce uncertainty in the future. This variable is measured by calculating the difference in years from the year the company was founded based on the deed of establishment to the time the company made a stock offering. Company age can be measured by the equation:

\section{$A G E=\operatorname{Ln}($ Research year - The year the company was founded)}

To determine the effect of the independent variable on the dependent, Multiple Regression is used. The data used are secondary data in the form of a prospectus for offering shares, initial share price, closing share price after listing on the secondary market, and the Company's financial statements at the time of the IPO. Data was also collected from various mass media, the Capital Market Journal, The Indonesian Capital Market Institute (TICMI) and the Indonesian Capital Market Directory (ICMD). The Multiple Regression Equation for each model in this study are:

$Y U P=b 0+b 1 D E R+b 2 R O A+b 3 Q R+b 4 F S+b 5 B H+b 6 R U+b 7 A F+e$ 
Information :

YUP : Underpricing

b0 : Constant

b1 - b7: Regression coefficients of each independent variable

DER : Debt to Equity Ratio

ROA : Return on Assets

QR : Quick Ratio

FS : Firm Size

$\mathrm{BH}$ : Blockholder

RU : Underwriting Reputation

AF : Age Firm

To find out how far the influence of one independent variable individually in explaining the variation of the dependent variable is used $t$ statistical test. The proof is done by comparing the results of $t$ and $t$ table. Determining the two-sided test criteria $\mathrm{H} 0$ is accepted if $-\mathrm{t}(\alpha / 2 ; \mathrm{n}-1) \leq \mathrm{tcount} \leq \mathrm{t}(\alpha / 2 ; \mathrm{n}-1)$ (probability value (sig value) $<\mathrm{a})$. H0 is rejected if tcount $<-\mathrm{t}(\alpha / 2 ; \mathrm{n}-1)$ or tcount $>\mathrm{t}(\alpha / 2 ; \mathrm{n}-1)$ (probability value (sig value) $\geq \mathrm{a})$.

\section{Result}

Based on the results of calculations using the Eviews 9 program, a summary of the calculation of the regression analysis of the effect of DER, ROA, Quick Ratio, Firm Size, Blockholder, Underwriting Reputation, Age Firm on underpricing can be seen in Table 1 .

Table 1: Results of Regression Analysis

\begin{tabular}{|l|c|c|c|c|}
\hline Variable & Coefficient & Std. Error & t-Statistic & Prob. \\
\hline C & 0.456520 & 0.032867 & 9.634821 & 0.0000 \\
\hline X1DER & $-3.08 \mathrm{E}-03$ & $2.22 \mathrm{E}-01$ & -1.554309 & 0.0378 \\
\hline X2ROA & $-2.78 \mathrm{E}-90$ & $1.06 \mathrm{E}-21$ & -0.725541 & 0.0413 \\
\hline X3QR & $-1.03 \mathrm{E}-12$ & $1.54 \mathrm{E}-12$ & -0.112673 & 0.0028 \\
\hline X4FS & -0.160669 & 0.065481 & -3.355267 & 0.0129 \\
\hline X5BH & 0.000359 & 0.005248 & 0.256712 & 0.0039 \\
\hline X6RU & $5.93 \mathrm{E}-10$ & $1.23 \mathrm{E}-14$ & 0.911078 & 0.0040 \\
\hline X7AF & $-2.16 \mathrm{E}-37$ & 0.001335 & -0.013352 & 0.0191 \\
\hline
\end{tabular}

Based on the results of statistical calculations using the Eviews 9 program, it is concluded that the probability value of DER in the study has a probability value of 0.0378 , ROA has a probability value of 0.0413 , Current Ratio has a probability value of 0.0028 , the probability value in the Firm Size variable is 0.0009 , Blockholder has a probability value of 0.0039 , Underwriter's Reputation has a probability value of 0.0040 , and Age Firm has a probability value of 0.0191 , which means that all variables are still smaller than the significance level of 0.05 or $\alpha 5 \%$ or 0.10 or $\alpha 10 \%$ and also can be said to affect the underpricing variable. 
The F test is used to test the feasibility of the model shown in Table 2 below:

Table 2: Simultaneous Regression Coefficient Test Results (Test F)

\begin{tabular}{|l|l|l|l|}
\hline F-statistic & 2.176572 & Durbin-Watson stat & 1.876521 \\
\hline Prob(F-statistic) & 0.012276 & & \\
\hline
\end{tabular}

Table 2 shows that the F-statistic value is 2.176572 with a $\mathrm{p}$ value of 0.012276 where $<0.05$, so it can be concluded that the model developed is feasible, meaning that the underpricing variable can be explained by the DER, ROA, Quick Ratio, Firm Size, Blockholder, Underwriter Reputation, and Age Firm.

From Table 3, the results of the regression test show the coefficient of determination (R2) of 0.172015 . This result means that there is a contribution of $17.2 \%$ of the variables DER, ROA, Quick Ratio, Firm Size, Blockholder, Underwriting Reputation, and Age Firm to Underpricing. While the remaining $82.3 \%$ is explained by financial variables and other non-financial variables which are not examined in this study.

Table 3: Coefficient of determination R2

\begin{tabular}{|l|c|l|c|}
\hline R-squared & 0.192039 & Mean dependent var & 0.686494 \\
\hline Adjusted R-squared & 0.108891 & S.D. dependent var & 0.277126 \\
\hline S.E. of regression & 0.307616 & Akaike info criterion & -0.406938 \\
\hline Sum squared resid & 3.728179 & Schwarz criterion & -0.054981 \\
\hline Log likelihood & 19.47890 & Hannan-Quinn criter. & -0.152816 \\
\hline F-statistic & 2.710962 & Durbin-Watson stat & 1.937641 \\
\hline Prob(F-statistic) & 0.023917 & & \\
\hline
\end{tabular}

\section{Discussion}

Underpricing is influenced by accounting information and non-accounting information in the prospectus of the company that will conduct the IPO. Accounting information is a financial report consisting of a balance sheet, profit / loss statement, cash flow statement and financial statement explanation, which in this study is called financial variables. Non-accounting information is information other than financial reports such as underwriters, independent auditors, legal consultants, share offering value, percentage of shares offered, company age and other information, which in research is called nonfinancial variables.

The test results show that the blockholder variable has a probability value of 0.00359 , this value is less than 0.05 or $\alpha 5 \%$. The positive direction of the regression coefficient explains that the larger the blockholder variable, the greater the level of underpricing. This means that there is a direct relationship between the blockholder variable and the underpricing variable. This is in line with the research conducted by Connell \& Servaes (1990) which found a positive relationship between blockholder variables and underpricing variables. The concentration of ownership (blockholder) indicates that there are controlling shareholders in the company. If the company decides to sell shares to the public, it will result in changes in the capital structure. This has an 
impact on the emergence of potential new investors' concerns about the active control of old shareholders. Blockholders make the decision to set a smaller number of publicly traded shares in order to retain control over the company. With the high demand for company shares, an increase in share prices will occur in the secondary market which will increase the level of underpricing.

Based on the results of the analysis, it shows that the underwriter's reputation variable has a positive effect on the underpricing variable with a probability value of $0.0040<0.05$. Looking from the point of view of agency theory, it shows that the positive effect of audit quality on underpricing is because the issuer is assessed by the market and can transparently use a reputable auditor. This is also in line with Irawan \& Pangestuti's (2015) research. The better the quality of the underwriter based on the ranking, the ability to measure and understand the market can help the issuer gain investor confidence. Thus, risk factors such as uncertainty can be minimized.

Based on the results of the analysis, it shows that the DER variable has a probability value of 0.0378 . This value is smaller than 0.05 . It can be concluded that the DER variable has an influence on the underpricing variable. The regression coefficient of -3.08E-03 indicates that DER has a negative effect on underpricing. This study is in accordance with the results of Pakpahan and Sembiring (2015) which suggest that the effect of DER on underpricing has a negative direction. A high DER level in a company will have an impact on the company's risk of paying high long-term obligations. This is avoided by the issuer because it will have a negative impact on the company's performance.

Based on the results of the analysis, it shows that ROA (Return on Asset) has a negative effect on the underpricing variable. Based on the test results, it shows that the regression coefficient on the ROA variable is $-2.78 \mathrm{E}-90$, with a significance of 0.0413 . This study is in accordance with the results of Astuti and Syahyunan (2013) which explain that ROA has a negative effect on the underpricing variable. The amount of ROA for the company will affect the high return on investment for investors.

The effect of the current ratio on the underpricing variable has a probability value of 0.0028 , this value is smaller than 0.05 . So it can be said that the current ratio has an effect on underpricing. This study is in accordance with the results of Raharja (2014), Risal (2014) and Aridhonda (2013) which state that the current ratio has a negative effect on the underpricing variable. The variable current ratio is an indicator in determining the company's ability to meet its short-term obligations. This variable can be obtained from the amount of the company's current assets to current debt. The effect of the current ratio variable on the underpricing variable can explain that the behavior of investors is paying attention to the level of current ratio when buying shares in the primary market.

The regression results show that the firm size variable has a probability value of 0.0129 , which is less than 0.05 . The coefficient value is $-1.03 \mathrm{E}-12$. So it can be said that firm size affects the underpricing variable. This is in line with research by Sukma (2013) which shows the results of the analysis that company size affects the level of stock underpricing. Firm Size has a negative effect, it means that the size of the company has an impact on the stock price when it is offered. So that the greater the size of the company, the lower 
the level of underpricing of shares due to the level of uncertainty or low risk. The large size is easily recognized by many investors and information about the company is quite widely circulating in the public. The amount of information circulating can reduce the level of uncertainty in the future.

The age of the company (age firm) can indicate the length of time that a company has been established and operated with the perception that the greater the age, the lower the risk level. So that it can attract investors because it is believed that a long-established company can survive and have experience in producing good returns. Later, it will have a long-term impact on the rate of return obtained by investors in the future. Based on the test results on the age firm variable, it has a probability value of 0.0191 . This value is lower than 0.05 , so it can be said that firm age has an effect on underpricing. The results found are in line with research by Rosyati \& Sabeni (2012) and Sandhiaji (2014) which states that there is a negative influence on company age on underpricing. In this case, investors consider the age of the firm in analyzing a company. The older the company does not guarantee good performance and has a lot of information to reduce the risk of uncertainty for investors.

\section{Conclusion}

Based on data analysis and discussion related to the problem of the influence of financial and non-financial variables on underpricing, it is concluded that blockholders in a company have an influence on the level of underpricing. The greater the percentage of ownership in a company, the greater the level of underpricing. Underwriter's reputation can influence the decisions of capital market investors, because in this study there is a positive effect but on underpricing. Investors may consider that a good underwriter's reputation minimizes the risk of uncertainty. Debt to Equity Ratio (DER) has a negative effect on the underpricing variable. Investors consider the level of debt of the company before deciding to invest in the company. Return on Asset (ROA) has a negative effect on the underpricing variable. The amount of ROA for the company will affect the high return on investment for investors. Current Ratio affects underpricing. The negative effect of the current ratio value on the underpricing variable can explain that the higher the current ratio value in a company is considered by investors that the company has a good level of liquidity. Firm size has an effect on underpricing. So that the greater the size of the company, the lower the level of underpricing of shares due to the level of uncertainty or low risk. Firm age (firm age) affects the underpricing variable. The older the company is considered to have a good performance and has a lot of information to reduce the risk of uncertainty for investors.

For company management that will conduct an IPO on the Indonesia Stock Exchange with the aim of obtaining funding, it is better if you pay attention to the level of financial and non-financial variables that can affect the level of underpricing. With a low level of underpricing, it is expected that the company can receive more funds from selling shares in the capital market. This study has limitations, where the variables used 
in this study are still considered lacking. For future research, it is expected to add variables both financial and non-financial variables.

\section{References}

Abdullah, Nur-Adiana H. and Kamarun N. T. Mohd. 2004. Factors Influencing the Underpricing of Initial Public Offering in an Emerging Market: Malaysian Evidence. IIUM Journal of Economics and Management, Vol 12, No. 2

Agus Kretarto, Investor Relation: Pemasaran dan Komunikasi Keuangan Perusahaan Berbasis Kepatuhan, Grafiti Pers, 2001

Ang, Robert. 1997. Buku Pintar Pasar Modal Indonesia, Mediasoft Indonesia. Jogiyanto. 2000. “Teori Portofolio dan Analisa Investasi"Edisi Ketiga BPFE, Yogyakarta.

Ardiansyah, Misnen. 2003. Pengaruh Variabel Keuangan Terhadap Return Awal dan Return 15 Hari Setelah IPO di Bursa Efek Jakarta. Makalah SNA VI.

Ardiansyah, Misnen. 2004. Pengaruh Variabel Keuangan terhadap Return Awal dan Return 15 hari setelah IPO serta Moderasi Besaran Perusahaan terhadap Hubungan antara Variabel Keuangan dengan Return Awal dan Return 15 hari setelah IPO di BEJ. Jurnal Riset Akuntansi Indonesia, Vol.7, No.2.

Aridhonda. (2013). Pengaruh Likuiditas, Total Asset Turnover, Ukuran Perusahaan dan Umur Perusahaan Terhadap Initial Return.

Asiri, B., \& Haji, A. (2015). The Determinants of IPO Underpricing in the GCC Countries. International Journal of Arts E Sciences, 205-217.

Astuti, Asih Yuli dan Syahyunan. 2013. Pengaruh Variabel Keuangan dan Non Keuangan Terhadap Underpricing Pada Saham Perusahaan yang Melakukan Initial Public Offering di Bursa Efek Indonesia. Jurnal Media Informasi Manajemen, 1-13.

Budi Harsono, Efektif Bermain Saham (Jakarta: kompas Gramedia, 2013)

Brigham, Eugene F and Joel F. Houston. 2009. Fundamentals of Financial Management. 12th Edition. Mason: South-Western Cengage Learning.

Carter, Richard \& Steven Manast, er, 1990, "Initial Public Offerings and Underwriter Reputation", Journal of Finance, Vol. XLV, No. 4.

Dimovski, William and Robert Brooks. 2008. The Underpricing of Gold Mining Initial Public Offerings. Research in International Business and Finance, Vol 22, No.1, (January).

Eungene F. Brigham dan Joel F. Houaton, Manajemen Keuangan, Erlangga, Jakarta, 2001 Florin, J., \& Simsek, Z. (2007). The Effects of Moral Hazard and Adverse Selection on The Pricing and Underpricing of Initial Public Offerings. Venture Capital, 127-143.

Garrison, Ray H., Eric W. Noreen, \& Peter C. Brewer. 2013. Akuntansi Manjerial Buku 2. Edisi Keempatbelas. Penerjemah: Kartika Dewi. Jakarta Salemba Empat.

Herawati, A. (2017). The Factors Affecting Initial Return on IPO Company in IDX 2007 2012. International Journal of Economic Perspectives, 1499-1509. 
Irawan, P \& Pangestuti, I. Pengaruh Struktur Kepemilikan, Corporate Governance, dan Underwriter Reputation terhadap IPO Underpricing. Diponegoro Journal of Management. 1-12

Jogiyanto, Teori Portofolio dan Analisa Investasi, BPEE UGM, Yogyakarta, 2000

Karina, Rita. 2015. Analisa Faktor-faktor Yang Mempengaruhi Tingkat Underpricing Saham Pada Perusahan Non-Keuangan Yang Melakukan IPO di Bursa EFEK Indoesia Periode 2003-2012. Jurnal Ilmiah Mahasiswa Universitas Surabaya Vol.4 No. 2

Linazah, L. Nisvi, \& Setyowati T. 2015. Faktor-faktor yang Mempengaruhi Underpricing Pada Perusahaan yang Melakukan Penawaran Umum Perdana Di Bursa Efek Indonesia. Jurnal Manajemen dan Bisni Vol.1 No.1 Juni 2015.

Low, S., \& Yong, O. (2011). Explaining Over-Subscription in Fixed-Price IPOs: Evidence from the Malaysian Stock Market. Emerging Markets Review, 205-216.

Maulidya, P. S., \& Lautania, M. F. (2016). Pengaruh Asset Turnover, Current Ratio, Debt to Equity Ratio, dan Ukuran Perusahaan Terhadap Terjadinya Underpricing Saham Pada Perusahaan Di Pasar Penawaran Saham Perdana Yang Terdaftar Di Bursa Efek Indonesia. Jurnal Ilmiah Mahasiswa Ekonomi Akuntansi (JIMEKA), 1(1), 171-182.

Mochamat Feri, "Pengaruh Rasio Profitabilitas Terhadap Perubahan Harga Saham Pada Perusahaan Sektor Properti Yang Listing di Bursa Efek Indonesia Periode 20082012", Jurnal Manajemen Vol. Nomer 6, Universitas Negeri Surabaya, Surabaya, 2013

Muhamamad Umar Mai, “Keputusan Struktur Modal, Tingkat Produktivitas dan Profitaibilitas, Serta Nilai Perusahaan (Kajian Atas Perspektif Teori Dasar Struktur Modal) Pada Perusahaan Manufaktur di Bursa Efek Indonesia Periode 2010-2012", Jurnal Ekonomi dan Bisnis, Vol 12, No 1, 2013.

Nurhidayati, Siti \& Nur Indriantoro, 1998, “Analisa Faktor-faktor yang Berpengaruh terhadap Tingkat Underpriced pada Penawaran Perdana di Bursa Efek Jakarta", Jurnal Ekonomi dan Bisnis Indonesia , Vol.13 , No.1.

Pahlevi, R. W. (2014). Underpricing Saham Pada Penawaran Saham Perdana. Jurnal Siasat Bisnis, 18(2), 219-232.

Putra, I. S., \& Nababan, D. (2019). Influence of Non-Financial Information and Macroeconomic on the Level of Underpricing on Companies that Conduct IPO on the IDX in the 2011-2015 Period. Global Business and Management Research, 341-354.

Raharja, D. T. R. (2014). Analisis Pengaruh Faktor Fundamental Perusahaan. Diponegoro Journal of Accounting, 3, 1-12.

Rifqi Muhammad, Akuntansi Keuangan Syariah (Yogyakarta: P3EI, 2010), 61.

Risal. (2014). Underpricing: Informasi Akuntansi Dan Non Akuntansi Dalam Initial Public Offering (Ipo). Akuntablititas, VII(1), 42-55.

Rosyati dan Sabeni, Arifin. 2012. Analisis faktor-faktor yang mempengaruhi underpricing saham pada perusahaan Go Publik di Bursa Efek Jakarta (Tahun 2000-2010). Kumpulan Makalah Simposium Nasional Akuntansi V. 286-297. 
Sandhiaji, Bram Nugroho. 2014. Analisis faktor-faktor yang mempengaruhi tingkat underpricing pada penawaran umum perdana (IPO) periode tahun 2009-2014. Universitas Diponegoro, Semarang.

Sartono, R. Agus. 2010. Manajemen Keuangan Teori dan Aplikasi Buku 1. Edisi keempat. BPFE: Yogyakarta.

$\mathrm{Su}$, Dongwei. 2004. Leverage, Insider Ownership and the Underpricing of IPOs in China. Journal of International Financial Markets Institutions \& Money, Vol 14.

Suad, H, Dasar-Dasar Teori Portofolio dan Analisa Sekuritas (Yogyakarta: UPP ykpn, 2010)

Sukma, A. Candra. (2013). Analisis Faktor-Faktor yang Memperngaruhi Underpricing Saham pada Pernawaran Umum Perdana di Bursa Efek Indonesia tahun 20092011. Tesis. Yogyakarta: Universitas Negeri Yogyakarta.

Sulistio, H. 2005. Pengaruh Informasi Akuntansi dan Non Akuntansi Terhadap Initial Return: Studi pada Perusahaan yang Melakukan Initial Public Offering di Bursa Efek Jakarta. SNA VIII Solo.

Suyatmin dan Sujadi. 2006. Faktor-faktor yang Mempengaruhi Underpricing pada Penawaran Umum Perdana di Bursa Efek Jakarta. BENEFIT, Vol.10, No.1

Tajuddin, A. H., Mohd Rashid, R., Abdullah, N., \& Abdul-Rahim, R. (2015). An Empirical Examination of Over-Subscription in the Malaysian IPO Market. International Journal of Economics and Management, 81-102.

Wahyudi, S. 2004, "Pengaruh Umur Perusahaan dan Ukuran Perusahaan sebagai Assurance terhadap Return Awal Saham", Jurnal Bisnis dan Akuntansi , Vol.6, No.2.

Wahyusari, A. 2013. Analisa Faktor-Faktor yang Mempengaruhi underpricing saham saat Initial Public Offering. Jurnal Akuntansi. Semarang.

Zaenal, A. 2005. Teori Keuangan dan Pasar Modal, Ekonosia, Yogyakarta. 
Dyan Fajar Mahardika, Fitri Ismiyanti

THE EFFECT OF FINANCIAL AND NON-FINANCIAL VARIABLES ON UNDERPRICING

Creative Commons licensing terms

Authors will retain copyright to their published articles agreeing that a Creative Commons Attribution 4.0 International License (CC BY 4.0) terms will be applied to their work. Under the terms of this license, no permission is required from the author(s) or publisher for members of the community to copy, distribute, transmit or adapt the article content, providing a proper, prominent and unambiguous attribution to the authors in a manner that makes clear that the materials are being reused under permission of a Creative Commons License. Views, opinions and conclusions expressed in this research article are views, opinions and conclusions of the author(s). Open Access Publishing Group and European Journal of Economic and Financial Research shall not be responsible or answerable for any loss, damage or liability caused in relation to/arising out of conflict of interests, copyright violations and inappropriate or inaccurate use of any kind content related or integrated on the research work. All the published works are meeting the Open Access Publishing requirements and can be freely accessed, shared, modified, distributed and used in educational, commercial and non-commercial purposes under a Creative Commons Attribution 4.0 International License (CC BY 4.0). 